\title{
Paper Presented
}

In

International Conference on Contemporary Issues in Commerce, Economics and Management

$10^{\text {th }}$ December, 2015

Published

In

International Journal of Multifaceted and Multilingual Studies

(Special Issue - 1)

Vol.II(3), December, 2015

ISSN 2394-207X (Print) 


\section{ebanking in India}

\section{Yogesh Prasad Kolekar}

Asst. Prof, Ismailsaheb Mulla Law College, Satara

Asst. Prof in business law, D. G. College of Commerce, Satara

Today we live in a technology driven world. Industrial revolution gave birth to giant machines for industrial advancement and information technology has delivered intelligent machines to revolutionize human development. Today we are surrounded by automated smart technology, which has touched almost all spheres of human life, from military to medicine and from education to the election. ${ }^{1}$ Electronic banking or e-banking is the fusion of information technology with the banking system. The dictionary.cambridge.org ${ }^{2}$ defines electronic banking as,

"The use of the internet to organize, examine, and make changes to your bank accounts and investments, etc. electronically, or the use of the internet by banks to operate accounts and services."

The Oxforddictionaries.com ${ }^{3}$ defines it as

"A method of banking in which the customer conducts transactions electronically via the Internet"

The bankersonline.com defines electronic banking as,

"Electronic banking is an umbrella term for the process by which a customer may perform banking transactions electronically without visiting a brick-and-mortar institution. The following terms all refer to one form or another of electronic banking: personal computer $(P C)$ banking, Internet banking, virtual banking, online banking, home banking, remote electronic banking, and phone banking. PC banking and Internet or online banking are the most frequently used designations. It should be noted, however, that the terms used to describe the various types of electronic banking are often used interchangeably"

Thus the term electronic banking generically refers to various terms connected with virtual banking and often interchangeably used with the term internet banking. ${ }^{4}$

\footnotetext{
${ }^{1}$ Sujata Pawar and Yogesh Kolekar, Essentials of Information Technology law, Notionpress.com, 2015

${ }^{2}$ http://dictionary.cambridge.org/dictionary/british/electronic-banking

${ }^{3} \mathrm{http}: / / \mathrm{www}$.oxforddictionaries.com/definition/english/e-banking

${ }^{4}$ https://www.iobnet.co.in/newapps/html/terms.html
} 


\section{History of ebanking in India}

The Rangarajan Committees ${ }^{5}$ drew a phased plan for bank computerization in the 1980's which recommended computerization of banks at various levels. The second Rangajan committee made important recommendation, including computerization of branch and connectivity between branch and establishment of ATM at strategically important places like airports, railway stations, hospitals, etc. The HSBC bank introduced ATM ${ }^{6}$ services in India in 1987 at Mumbai and Bank of India was among the first nationalized bank to introduce ATM services at its Mahalaxmi branch in Mumbai in the year 1989. In India, ICICI bank for the first time introduced an internet banking facility ${ }^{7}$ followed by City bank and HDFC bank. ${ }^{8}$

The systematic use of Core Banking Solution (CBS) was another milestone development in the history of ebanking in India. The Synidicate Bank was the first public sector bank to launch Core Banking Solution in the year 2001 in Bangalore. ${ }^{9}$ The Introduction of NEFT ${ }^{10}$ and RTGS ${ }^{11}$ eased the nationwide transfer of funds and led to further growth of ebanking in India. The 'Institute for the development and Research in Banking Technology' (IDRBT) established in Hyderabad in mid nineties played a vital role in the facilitation of ebanking technology. ${ }^{12}$

\section{Computerization}

The Rangarajan committee reports in the year $1984^{13}$ and $1989^{14}$ recommended computerization of banking process which led to computerization of banking operation in India. In order to avoid hassle on the mechanization of the banking system, bank management signed an agreement with the Employees Union of Banks in the year 1983, for mechanization of banking operation, which allowed use of electric/electronic machines and mainframe computer in branches, zonal offices and head offices. However, this agreement had limited scope as it restricted the use of electronic devices in certain specific areas only. Later in the year 1993 another agreement was signed with the Indian Banks Association for consenting to using of computers, which eventually paved the way for computerization of banking operation. ${ }^{15}$ The computerization was a giant step that led to further development of ebanking in India.

\footnotetext{
${ }^{5}$ Under the chairmanship of Dr. C Rangarajan, Governor of the Reserve Bank of India, One in year 1984 and another in 1988 .

${ }^{6}$ Automated Teller Machines

${ }^{7}$ http://www.gkduniya.com/bank-india

${ }^{8} \mathrm{http}: / /$ indianresearchjournals.com/pdf/APJMMR/2012/December/2.pdf

${ }^{9} \mathrm{http}: / / \mathrm{www}$. business-standard.com/article/finance/syndicate-to-bring-1500-branches-under-cbs106120101062_1.html

${ }^{10}$ National Electronic Fund Transfer

${ }^{11}$ Real Time Gross Settlement

${ }^{12}$ Technology in Banking- In Pursuit of Excellence, Address by Shri Anand Sinha, Deputy Governor, Reserve Bank of India at the IDRBT Banking Technology Awards at Hyderabad on August 4, 2011

${ }^{13}$ Committee on Mechanisation in the Banking Industry

${ }^{14}$ Committee on Computerisation in Banks

${ }^{15} \mathrm{http}$ ://importantbankingnews2.blogspot.in/2014/11/central-pay-commission-vs-bipartite.html
} 


\section{Automated Teller Machines ${ }^{16}$}

Automated Teller Machines or ATM are machines which provide customers to perform banking services like cash withdrawal, make deposits, check balance, cash transfer. ${ }^{17}$ The Automated Teller Machines popular called ATM assist in performing banking transactions without the aid of a bank teller. There are around 1.6 lakhs ATM's in India. ${ }^{18}$ An ATM service set up and operated banks and non banks, which is called as White Label ATMs. The RBI has authorized non banks to set up and operate ATM's with the object of increasing geographical presence of ATMs under the Payment and Settlement Sytem Act, 2007. ${ }^{19}$

An ATM apart from performing cash dispensing facility also provides following services. ${ }^{20}$
a) Cash deposit
b) Balance inquiry
c) Mini statement of account
d) Bill payments
e) Cheque book request
f) Money transfer

\section{Cards - debit card, credit card and prepaid cards}

Debits are issued by banks which are linked to the customer's bank account. A debit card is used for cash withdrawal from ATMs, purchase of goods and services and for online transactions.

A credit card is issued by a bank and other institution authorized by the RBI and can be used for the limit sanctioned by the bank. Both debit card and credit can be used internationally, if enabled by the bank. The important difference between debit card and credit card is that in debit card, the customer usages money available in his account and in credit card a customer can utilize the amount up to the line of credit sanctioned by the bank. A prepaid card is issued by the banks and non banks and is used primarily for the purpose of purchase of goods and services

\footnotetext{
${ }^{16}$ Also known as automated teller, automatic-teller machine, cash machine, money machine http://dictionary.reference.com/browse/automated-teller\%20machine

${ }^{17} \mathrm{http}: / / \mathrm{www}$.businessdictionary.com/definition/automated-teller-machine-ATM.html

${ }^{18} \mathrm{http}$ ://zeenews.india.com/business/news/finance/rbi-cuts-number-of-free-cross-bank-atm-transactions-to-3-permonth_106151.html

${ }^{19}$ https://rbi.org.in/scripts/FAQView.aspx?Id=75

${ }^{20} \mathrm{http} / / / \mathrm{www}$. banknetindia.com/atm/functionality.htm
} 
against the value stored in it. A prepaid card issued by banks can also be used for fund transfer within the country. ${ }^{21}$

\section{Internet banking}

The RBI had constituted a Working Group to study and recommend issues relating to internet banking and concurrently the banks have constituted an Operational Group to guide in the implementation of the recommendations of the Working Group. The Working Group held its first meeting in the year 2000 and recommended on different aspect of internet banking and appropriate standard for Indian banking sector. ${ }^{22}$ The ICICI was the pioneer to introduce internet banking to its customers in the year $1998^{23}$ and other banks like HDFC Bank Ltd. Citibank, Global Trust Bank Ltd., UTI Bank Ltd., Bank of Madura Ltd., Federal Bank Ltd. etc. were leading players to deploy internet technology for its customer. ${ }^{24}$

Internet banking which is also commonly referred as online enjoys a host of advantage over a traditional banking system. Internet banking allows better control and access to one's account. One can access account any time and avail certain service like checking of balance, fund transfer, creating of fixed deposits, managing investment, paying of utility bills. ${ }^{25}$

\section{Electronic Fund Transfer - NEFT/RTGS/IMPS}

The electronic fund transfer occupies an important place in the banking system which makes possible transfer of money from one account to another electronically. National electronic Fund Transfer is an inter bank and inter branch fund transfer system. In NEFT, an individual, firm or a corporate can transfer money from one bank to another bank or branch. The RBI acts as service provider and facilitate transfer of money between different banks and branches. The NEFT transactions are settled in batches. ${ }^{26}$ There is no minimum or maximum limit on the amount of transfer in NEFT. 27

The RTGS stands for Real Time Gross settlement which provide real time settlement of funds. The main difference between NEFT and RTGS is that in the NEFT settlement of transaction works on settlement cycle and any transaction made after the settlement cycle have to wait till the next settlement cycle whereas in RTGS settlement is processed throughout the business hour of the banks. The RTGS is primarily meant large amount transaction and a minimum amount for an RTGS transaction is 2 lakhs.

\footnotetext{
${ }^{21}$ https://rbi.org.in/scripts/FAQView.aspx?Id=103

${ }^{22}$ Report on Internet Banking,22 Jun 2001, https://www.rbi.org.in/scripts/PublicationReportDetails.aspx?ID=243

${ }^{23} \mathrm{http}: / / \mathrm{www} . \mathrm{moneycontrol.com/company-facts/icicibank/history/ICI02}$

${ }^{24} \mathrm{https}$ ///www.rbi.org.in/scripts/PublicationReportDetails.aspx?ID=243

${ }^{25} \mathrm{http} / / / \mathrm{www} . \mathrm{hsbc} . c 0 . i n / 1 / 2 /$ personal/internet-and-self-service-banking/internet-banking/services-password

${ }^{26}$ NEFT operates on hourly batches, fom 8 am to $7 \mathrm{pm}$ on week days and 8 am to 1 pm on Saturdays.

${ }^{27} \mathrm{https} / / /$ www.sbi.co.in/portal/web/customer-care/faq-rtgs-neft
} 
Immediate Payment Service is the fund transfer system, though mobile phone, ATM and internet banking. To avail this service, the customer has to register his mobile phone number with the bank and a seven digit code is given to the customer number as MMID number. ${ }^{28}$

\section{Mobile Banking}

Mobile banking a new recent development in banking technology was first launched by HDFC $^{29}$ and among nationalized bank it was Union Bank of India. ${ }^{30}$ Mobile banking is the use of mobile phones to access or to conduct banking account which is generally done through SMS, USSD or mobile banking application or apps.

Mobile banking has greatly increased and in the near future would overtake internet banking transaction. As per RBI report mobile banking has increased five times over a year from Rs 3296 in 2014 to Rs 18862 in $2015^{31}$

\section{Conclusion}

Information Technology has brought vital changes and challenges in the banking sector worldwide. The journey of banking technology started with computerization and ATM's and has now reached into individuals mobiles. This has enhanced speed and convenience, but also exposed to risk of cybercrime or phishing. ${ }^{32}$ A Phishing is a crime of fraud or deception through emails. The perpetrator sends email resembling legitimate one to lure the user to reveal a password or financially vital code. ${ }^{33}$

The Assocham ${ }^{34}$ India has recently brought forward alarming figures ${ }^{35}$ that the number of cyber crime may double in may double to three lakh in 2015 largely due to increased use of smartphones and tablets for online financial transactions. According to Ultrascan Advanced Global Investigation report, it is found that in the year 2013, India stood in fourth position globally to lose money in the famous Nigerian email scam. ${ }^{36}$ Every year, thousands of people become victim of different email scams; hence it is necessary to take preventive steps.

The Phishing scammer is adopting novel practices to defraud innocent online users; hence, ultimately it would be in the interest of users to practice safe internet habits to keep oneself from

\footnotetext{
${ }^{28}$ Mobile Money Identifier

${ }^{29}$ http://www.hindustantimes.com/business/mobile-banking-gains-momentum-monthly-deals-up-150-in-2013/storygBUxw5gGu8f0xL4NnjpzLM.html

${ }^{30} \mathrm{http}$ ://articles.economictimes.indiatimes.com/2009-05-10/news/28466888_1_mobile-banking-balance-enquiryfirst-state-owned-bank

${ }^{31} \mathrm{http}: / /$ articles.economictimes.indiatimes.com/2015-07-02/news/64039019_1_mobile-banking-transactions-iwatch

${ }^{32}$ A critique on phishing crime in india, Yogesh Kolekar, LW (2015) June 6

33 http://searchsecurity.techtarget.com/definition/phishing

${ }^{34}$ The Associated Chambers of Commerce \& Industry of India

${ }^{35}$ Sunday, January 04, 2015, http://www.assocham.org/newsdetail.php?id=4821

${ }^{36}$ Ultrascan AGI is a subsidiary of Ultrascan Research Services, an International Research Organization that focuses on (internet) crimes such as Advance Fee Fraud (419), Corporate Identity Fraud, Credit Card Fraud etc.
} 
being hooked by a phishing scam. The following measure may help the user to secure oneself from phishing attacks. ${ }^{37}$

1. Keep your browser, operating system updated. Install only trusted antivirus with antiphishing features. $^{38}$

2. Never use links provided in email to use banks' websites. ${ }^{39}$

3. Use only secure URL for financial transaction. A secure web portal begins with https:// or a 'lock' pad icon. ${ }^{40}$

4. Do not respond to emails requesting your password or other financial details. The banks and other financial agencies do not send emails asking for vital financial details. In case of suspicion call your bank or visit personally. ${ }^{41}$

5. Do not close the browser without logging off. Always log off properly after completing transactions. ${ }^{42}$

${ }^{37} 31$ These suggestions should not be considered as legal advice or expert's advice and reader should consult qualified experts in this subject matter.

${ }^{38} 10$ Tips to Prevent Phishing Attacks, Available at http://www.pandasecurity.com/mediacenter/security/10tipsprevent-phishing-attacks/

${ }^{39}$ Ibid

${ }^{40}$ Five tips to secure mobile banking transactions, http://articles.economictimes.indiatimes.com/2014-07-

07/news/51133547_1_apps-text-message-mobile-banking-transactions

${ }^{41} \mathrm{https}: / /$ www.onguardonline.gov/phishing

${ }^{42} \mathrm{http}: / / \mathrm{www} . u n i o n b a n k o f i n d i a . c o . i n /$ per_internet_onlinesec.aspx 